\title{
Do awarded companies have fewer earnings management practices?
}

\author{
C. Kumandang \& N.S. Hendriyeni \\ Sekolah Tinggi Manajemen PPM, Jakarta, Indonesia
}

\begin{abstract}
This study aims to identify the influence of corporate social responsibility (CSR) and good corporate governance (GCG) on earnings management practices. CSR is proxied by the CSR award and GCG by the GCG award. Earnings management is measured by discretionary accruals and real earnings management. The population in this study involved all manufacturing companies listed on the Indonesia Stock Exchange whose financial reports were made fully available during the study period, that is, 2015-2019. The results of this study indicate that GCG and the number of awards received by the companies have a negative, but not significant effect on accrual earnings management and real earnings management practices, while CSR has a negative but not significant effect on accrual earnings management practices
\end{abstract}

\section{INTRODUCTION}

These days, companies require more than large profits to survive. They also have to show that they always pay attention to their stakeholders in their operation. The relationship between good corporate governance (GCG) and corporate social responsibility (CSR) lies in the principle of "accountability," which prioritizes stakeholders. Companies realize that their daily activities have an impact on their stakeholders, and they want to prepare it for them.

Transparency, openness, and accuracy in providing information to the stakeholders on time have attracted the attention of various institutions to evaluate the awarded companies that have properly implemented GCG principles. In Indonesia, many award events are held. However, this study considered that these two awards were the most appropriate because the assessment criteria were in line with this study. In addition, the awards are held regularly and organized by credible educational institutions. Both award events also call for strict requirements for registration, and the election of the winners is also carried out strictly based on predetermined criteria.

Logically, the company that wins the award should avoid unethical practices, such as earnings management due to the strict set of criteria. Unfortunately, a study that uses an award as a variable that affects earnings management has yet to be done. Hence, it can be said that this is the first study that used CSR and GCG awards as variables and their effects on earnings management.

\section{LITERATURE REVIEW}

\subsection{Earnings management}

The concept of earnings management, according to Jones (1991), consists of discretionary accruals, which are not reasonable, and non-discretionary accruals, namely, the level of accruals that are reasonable. Discretionary accrual is the recognition of accrual profit or expense that is free, unregulated, and a result of management policy choice, which can be manipulated to conform to the manager's policy. On the other hand, non-discretionary accrual is the recognition of accrual earning that is reasonable and in accordance with general accounting standards that can explain the 
company's varied economic conditions such as whether a depreciation will increase if a company's asset increases.

\subsection{Corporate Social Responsibility (CSR)}

Jones (1995) argues that companies that are committed to CSR provide incentives and are honest and ethical because they are aware that such behaviour will be the company's added value. Therefore, managers involved in CSR activities will be reluctant to practice earnings management because they are responsible for presenting transparent financial reports.

Consequently, CSR prevent the manager from performing earnings management. Thus, it is expected that there will be a negative relationship between CSR and earnings management practices. Therefore. the following hypothesis was formulated:

(H1): CSR has a negative effect on corporate earnings management practices.

\subsection{Good Corporate Governance (GCG)}

GCG is a system that regulates, manages, and supervises a business control process to increase share prices and is a form of concern for stakeholders, employees, and the surrounding community (Tunggal, 2013). According to Monks \& Minow (2003), GCG is a system that regulates and controls the company to create added value for all parties.

Therefore, it is expected that the implementation of GCG can curtail earnings management practices. Therefore, the following hypothesis was formulated:

(H2): The implementation of good corporate governance has a negative effect on earnings management practices.

\subsection{Awards}

An award-winning company is the one that truly pays attention to its stakeholders and does not only pursue profit. In this study, the award events that were held by the Indonesian Institute for Corporate Directorship (IICD) for GCG proxy and the Centre of Entrepreneurship, Change and Third Sector (CECT) - Trisakti University for CSR proxy were used.

The assessment criteria for the awards used in this study included the factors of GCG and transparency, which were used to determine winners, namely, companies with high-quality financial reports with low earnings management practices, constituting a negative relationship between receiving awards and earnings management practices. Therefore, the following hypothesis was formulated:

(H3): The number of awards received by the company has a negative effect on the company's earnings management practices.

\section{RESEARCH METHOD}

The number of samples used for this study was in accordance with the data of manufacturing companies listed on the IDX as of Sept 21, 2020. After an examination, 131 companies with complete financial data were found.

The proxies used to measure CSR and governance were the awards received by the companies from 2015 to 2019. Each award received equals 1 (one), and 0 (zero) score was given for no award. As for the "number of awards" variable, 1 (one) was given if the company received two awards and 0 (zero) was given if the company did not receive any awards or only received one award. The proxies used to measure earnings management were accrual earnings management, which is an absolute value, and real earnings management through operating cash flow. 
This study also included several control variables. It included the company size that was measured by the natural logarithm of a company's total assets with formula Ln (total asset), return on asset (ROA), return on equity (ROE), and the use of the big four public accountant service

The modified Jones model described by Dechow et al. (1995) was used to measure accrual earnings management as follows:

$\mathrm{DCA}=\mathrm{CA}_{\mathrm{i}, \mathrm{t}} / \mathrm{TA}_{\mathrm{i}, \mathrm{t}-1}-\left[\beta_{0}\left(1 / \mathrm{TA}_{\mathrm{i}, \mathrm{t}-1}\right)+\beta_{1}\left(\left(\Delta \mathrm{Sales}_{\mathrm{i}, \mathrm{t}}-\Delta \mathrm{TR}: \mathrm{TA}_{\mathrm{i}, \mathrm{t}-1}\right)+\beta_{2}\left(\mathrm{PPE}_{\mathrm{i}, \mathrm{t}} / \mathrm{TA}_{\mathrm{i}, \mathrm{t}-1}\right)+€_{\mathrm{i}, \mathrm{t}}\right.\right.$

where DCA is discretionary current accrual, CA is current accrual, TA is a total asset, $\Delta$ Sales is the difference between this year's sales and the previous year's $\Delta T R$ is the difference between this year's sales receivables and the previous year's and PPE is property plant and equipment.

The model used to measure REM in this study is as follows (Roychowdhury, 2006)

$$
\mathrm{CFO}_{\mathrm{t}} / \mathrm{TA}_{\mathrm{t}-1}=\mathrm{a}_{0}+\mathrm{a}_{1}\left(1 / \mathrm{TA}_{\mathrm{t}-1}\right)+\mathrm{b}_{1}\left(\mathrm{Sls}_{\mathrm{t}} / \mathrm{TA}_{\mathrm{t}-1}\right)+\mathrm{b}_{2}\left(\Delta \mathrm{Sls}_{\mathrm{t}} / \mathrm{TA}_{\mathrm{t}-1}\right)+€_{\mathrm{t}}
$$

The following regressions were used to test the hypotheses $(\mathrm{H} 1$ and $\mathrm{H} 2)$ and study the relationship between earnings management and CSR and GCG using several control variables:

$\mathrm{AEM}$ or $\mathrm{REM}=\mathrm{a} 0+\mathrm{b} 1 \mathrm{GCG}+\mathrm{b} 2 \mathrm{CSR}+\mathrm{b} 3 \mathrm{Big} 4+\mathrm{b} 4 \mathrm{ROA}+\mathrm{b} 5 \mathrm{ROE}+\mathrm{b} 6 \mathrm{Size}+\mathrm{e}$

To test the $\mathrm{H} 3$ hypothesis and identify the relationship between earnings management and the number of awards received by the company, the following regression model will be used:

$\mathrm{AEM}$ or $\mathrm{REM}=\mathrm{a}_{0}+\mathrm{b}_{1}$ Number of awards $+\mathrm{b}_{2} \mathrm{Big} 4+\mathrm{b}_{3} \mathrm{ROA}+\mathrm{b}_{4} \mathrm{ROE}+\mathrm{b}_{5}$ Size $+\mathrm{e}$

\section{RESULTS AND DISCUSSION}

Based on the available financial data, the relevant data was processed using the STATA-16 program. The regression results for accrual earnings management showed that hypotheses $\mathrm{H} 1$ and $\mathrm{H} 2$ were proven. It was found that the independent variables GCG and CSR were proven to have a negative effect on accrual earnings management practices. However, if viewed from its significance, both GCG and CSR had not been shown to have a significant effect on accrual earnings management practices. Meanwhile, the results of multiple regression for $\mathrm{H} 3$ showed that the number of awards received by the company had a negative effect on accrual earnings management practices, even though the effect was not significant. These results are similar to the study by Kumala and Siregar (2020), who found that CSR has a negative effect on accrual earnings management practices. Kamran and Shah (2014) found that the GCG mechanism has a negative effect on accrual earnings management practices. The regression results for all control variabels have a significant effect on accrual earnings management practices for all hypotheses. Size, ROE, and the big four have a negative effect, but ROA has a positive effect on accrual earnings management practices.

The regression results for real earnings management showed that the hypotheses $\mathrm{H} 2$ and $\mathrm{H} 3$ were proven. It was found that the independent variable GCG and the number of awards were proven to have a negative effect on real earnings management practices through operating cash flows, and this is similar to the study by Calvo (2015), who found that GCG has a negative effect on real earnings management practices through operating cash flows. However, H1 was not proven, since CSR had a positive effect on real earnings management practices through operating cash flows. This is similar to the study by M. Liu et al. (2017), who found that CSR does not affect real earnings management practices. However, if viewed from its significance, both GCG and CSR had not been shown to significantly influence real earnings management practices through operating cash flows. The regression results for all control variables have a positive but not significant effect on real earnings management practices through operating cash flows 


\section{CONCLUSION}

The results of this study suggest that awarding of GCG to companies and the number of awards received by a company had not been able to reduce the practice of accrual earnings management (AEM) and real earnings management through operating cash flows, even though the effect was negative. The awarding of CSR to companies also had not been able to reduce the practice of AEM, although the effect was negative. Meanwhile, it did not affect the practice of real earnings management through operating cash flows

These results are similar to the study by Subekti et al. (2010), who found that companies listed on the IDX generally practiced earnings management based on the company's operational activities. This also supports the study by Leuz et al. (2002), who succeeded in proving that Indonesia (an East Asian country) was one of countries that had weak protection against earnings management practices

Subsequently, the results mentioned above can be used as an input for investors and other stakeholders, which indicated that companies that receive awards from credible institutions can still be considered as investment options because they are proven to have better GCG and CSR practices than other companies.

\section{REFERENCES}

Calvo, S. G. (2015). Analysing The Relationship Between Corporate Social Responsibility, Discretionary Accruals And Real Earnings Management. Universiteit Van Amsterdam.

Dechow, P. M. (1995). Detecting Earnings Management Author(s): Detecting Earnings Management. The Accounting Review.

Jones, J. J. (1991). Earnings Management During Import Relief Investigations. Journal of Accounting Research. Jones, T. M. (1995). Instrumental Stakeholder Theory: A Synthesis of Ethics and Economics. Academy of Management Review.

Kamran, \& Shah, A. (2014). The Impact Of Corporate Governance and Ownership Structure On Earnings Management Practices: Evidence From Listed Company in Pakistan. The Lahore Journal of Economics.

Kumala, R., \& Siregar, S. V. (2020). Corporate Social Responsibility, Family Ownership and Earnings Management: The Case of Indonesia. Social Responsibility Journal.

Leuz, C. N. (2002). Investor Protection and Earnings Management: An International Comparison.

Liu, M., Shi, Y., Wilson, C., \& Wu, Z. (2017). Does family involvement explain why corporate social responsibility affects earnings management? Journal of Business Research,

Monks, R. A. (2003). Corporate Governance. Blackwell Publishing.

Roychowdhury, S. (2006). Earnings management through real activities manipulation. Journal of Accounting and Economics.

Subekti, I. W. (2010). The Real and Accruals Earnings Management: Satu Perspektif Dari Teori Prospek. Simposium Nasional Akuntansi XIII. Purwokerto.

Tunggal, A. W. (2013). Internal Audit dan Good Corporate Governance. Erlangga. 